\title{
Палеогеография Западно-Сибирского осадочного бассейна в позднем байосе - бате
}

Казаненков В. А.

\begin{abstract}
Аннотация
В статье представлены результаты региональных палеогеографических реконструкций ЗападноСибирского осадочного бассейна в позднем байосе - бате. Впервые построены и описаны региональные палеогеографические карты для этапов накопления продуктивных горизонтов Ю4, Ю3 и верхней части горизонта Ю2. Реализованный подход позволил получить представления об эволюции палеоландшафтов и сделать выводы об особенностях формирования верхнетюменской подсвиты и малышевской свиты в разных частях Западно-Сибирского осадочного бассейна. Построение палеогеографических карт основывалось на результатах фациальной интерпретации материалов геофизических исследований скважин, выполненной для отдельных частей малышевского горизонта с учетом материалов описания керна, а также палеонтологических, седиментологических, геохимических и других данных. Обсуждается палеогеографический контроль формирования пород-коллекторов в батском региональном резервуаре.
\end{abstract}

\section{Ключевые слова:}

Западная Сибирь, палеогеография, средняя юра, верхнетюменская подсвита, малышевская свита, продуктивные горизонты Ю2-Ю4 
УДК 551.8:551.762.22 (571.1)

\section{ПАЛЕОГЕОГРАФИЯ ЗАПАДНО-СИБИРСКОГО ОСАДОЧНОГО БАССЕЙНА В ПОЗДНЕМ БАЙОСЕ - БАТЕ}

\section{В.А. Казаненков}

Институт нефтегазовой геологии и геофизики им. А.А. Трофимука СО РАН, 630090, Новосибирск, просп. Академика Коптюга, 3, Россия

В статье представлены результаты региональных палеогеографических реконструкций Западно-Сибирского осадочного бассейна в позднем байосе - бате. Впервые построены и описаны региональные палеогеографические карты для этапов накопления продуктивных горизонтов $Ю_{4}, Ю_{3}$ и верхней части горизонта $Ю_{2}$. Реализованный подход позволил получить представления об эволюции палеоландшафтов и сделать выводы об особенностях формирования верхнетюменской подсвиты и малышевской свиты в разных частях Западно-Сибирского осадочного бассейна. Построение палеогеографических карт основывалось на результатах фациальной интерпретации материалов геофизических исследований скважин, выполненной для отдельных частей малышевского горизонта с учетом материалов описания керна, а также палеонтологических, седиментологических, геохимических и других данных. Обсуждается палеогеографический контроль формирования пород-коллекторов в батском региональном резервуаре.

Западная Сибирь, палеогеография, средняя юра, верхнетюменская подсвита, малышевская свита, продуктивные горизонты $Ю_{2}-Ю_{4}$

\section{ВВЕДЕНИЕ}

В настоящее время продуктивные горизонты $Ю_{2}-Ю_{4}$ проницаемого комплекса батского регионального резервуара являются важным объектом поисковых и разведочных работ на нефть и газ. Их нефтегазоносность доказана на огромной территории ЗападноСибирской нефтегазоносной провинции (НГП): от месторождения Победа в Предновоземельской нефтегазоносной области (НГО) на севере до Прирахтовского месторождения в Каймысовской НГО на юге и от Иусского месторождения в Приуральской НГО на западе до Термокарстового в Пур-Тазовской НГО и Хабейского в Енисей-Хатангской НГО на востоке. Фактически в пределах Западно-Сибирской НГП больше нет ни одного резервуара с такой обширной площадью нефтегазоносности. В значительной степени это обусловлено развитием регионального флюидоупора, представленного глинистыми толщами абалакской, нурминской, нижней части васюганской, точинской и гольчихинской свит. Из этого следует, что одним из главных факторов, определяющим формирование залежей углеводородов (УВ) в батском региональном резервуаре является наличие пород-коллекторов.

При изучении строения выявленных в верхнетюменской подсвите залежей УВ многими исследователями отмечалась невыдержанность по простиранию алевритопесчаных пластов $Ю_{2}-Ю_{4}$, изменчивость фильтрационно-емкостных свойств коллекторов и их сложное соотношение со структурным планом.

В такой ситуации наиболее достоверный прогноз распространения тел породколлекторов осуществляется с помощью палеогеографических реконструкций. При этом, с увеличением объема геолого-геофизической информации появляется возможность детализировать ранее выполненные построения и, в конечном итоге, повысить 
достоверность в определении закономерностей распространения песчаных тел, сформировавшихся в континентальных, переходных и морских обстановках осадочного бассейна.

Впервые на важность палеогеографических реконструкций при поисках и оконтуривании залежей нефти в континентальных отложениях указал И.М. Губкин [1912, 1913]. На основе детального изучения строения разрезов скважин и структурных построений по кровле эрозионной поверхности «фораминиферовых слоев» палеоцена и эоцена он выявил закономерности распространения коллекторов майкопской свиты Нефтяно-Ширвандского месторождения нефти. Это позволило ему сделать вывод о формировании песчаных тел, слагающих нефтенасыщенный коллектор, в русловых обстановках [Губкин, 1913].

За более чем вековой период после открытия И.М. Губкина залежи нефти и газа в песчаных коллекторах русловых фаций открыты во многих нефтегазоносных бассейнах (НГБ) мира.

Гипотезу о наличии залежей нефти в коллекторах руслового генезиса в ЗападноСибирском НГБ одним из первых выдвинул Ю.Н. Карогодин [1966]. Спустя 10 лет это научное предположение подтвердилось открытием в Красноленинском нефтегазоносном районе (НГР) на Талинской площади крупного по запасам месторождения нефти в песчано-гравелитовых пластах проллювиально-аллювиальных отложений нижней юры. Во второй половине 90-х гг. прошлого века по результатам комплексного анализа большого объема фактического геологического и геохимического материала была выделена гигантская Талинская зона нефтегазонакопления, модель геологического строения которой используется как один из эталонов неантиклинальных залежей углеводородов в континентальных отложениях Западно-Сибирского осадочного мегабассейна [Конторович и др., 1995].

\section{ИСТОРИЯ ВОПРОСА}

Изучение палеогеографии юрского периода Западно-Сибирского осадочного бассейна было начато в середине 50-х гг. прошлого века [Ростовцев, 1954] и шло в тесной связи с литолого-стратиграфическими исследованиями. По мере накопления новых палеонтологических, литологических и других материалов региональные стратиграфические схемы юры постоянно уточнялись и детализировались. Следствием этой детализации в палеогеографических исследованиях являлось постоянное сужение временных интервалов. Для изучаемого интервала верхнетюменской подсвиты, большая часть которого сложена отложениями батского яруса, по опубликованным работам прослеживается следующая последовательность.

Изначально палеогеографические карты и схемы на территорию ЗападноСибирского осадочного бассейна или отдельных крупных его регионов составлялись для ранней и средней эпох юры совместно [Казаринов, 1958; Гурова, Казаринов, 1962 ]. Позднее среднеюрские отложения были выделены в отдельный объект палеогеографических исследований [Гурари и др., 1963; Конторович и др., 1967; Саркисян и др., 1967; Гольберт и др., 1968 и др.].

В последующем палеогеография рассматривалась для временного интервала, объединяющего байосский и батский века [Атлас..., 1968; Атлас..., 1976], а в некоторых работах отдельно для батского века [Палеогеография..., 1983]. Палеогеографические карты для позднебатского времени приведены в работах [Мкртчян, Филина, 1985; Гурари и др., 1988].

Большинство исследователей рассматривали формирование отложений в батском веке на территории распространения тюменской свиты в континентальных обстановках, в 
условиях гумидного, теплого климата. Основанием для этого вывода служили характерные особенности строения разрезов, выраженные в наличии пластов и прослоев углей, а также обилии углистого детрита, остатков корневых систем и крупных фрагментов растений в породах. При этом предполагалось, что в северных районах, в разрезе верхнетюменской подсвиты могут быть встречены прослои морских отложений (особенно в верхней ее части), свидетельствующие о кратковременных ингрессиях моря в пределы низменной аккумулятивной равнины.

В Енисей-Хатангском региональном прогибе принималось накопление осадков в батском веке в условиях морского бассейна, что обосновывалось находками макро- и микрофауны в керне скважин и в обнажениях пород [Сакс, Ронкина, 1958; Палеогеграфия..., 1983].

Новый этап в истории палеогеографических реконструкций для эпох формирования отложений нижней и средней юры Западной Сибири начался в 90-х гг. прошлого века. Этому способствовало появление в 80-е гг. нового материала, полученного в результате выполнения большого объема глубокого бурения и региональной сейсморазведки, особенно в северных и арктических районах, где разрезы нижней и средней юры оставались до этого слабо изученными геологоразведочными работами.

Отличительной особенностью этого этапа стало проведение палеогеографических реконструкций не по векам юры, а по региональным стратиграфическим горизонтам, которые представляют собой литологически обособленные толщи, сформировавшиеся в трансгрессивные и регрессивные стадии развития осадочного бассейна. Границы этих толщ, как правило, не совпадают с границами ярусов. Наиболее активно палеогеографические исследования такого плана выполнялись специалистами СНИИГГиМСа под руководством В.С. Суркова и Ф.Г. Гурари [Девятов, Казаков, 1991; Атлас..., 1995; Гурари и др., 2005]. При этом следует отметить, что от первой работы к более поздней для малышевского времени отмечается тенденция увеличения акватории моря в направлении с севера на юг. В последней из указанных работ - [Гурари и др., 2005] распространение моря на юге осадочного бассейна показано до широты г. Омска, включая северо-западные и северные районы Новосибирской области, а на юго-востоке до г. Колпашево.

Изучение палеогеографии Западной Сибири в юрском периоде заметно активизировалось за последние 15 лет. Свидетельством этому является большое количество публикаций, в которых рассмотрены, как Западно-Сибирский осадочный бассейн в целом [Гурари и др., 2005; Мясникова и др., 2012; Kontorovich et al., 2013; Курчиков, Бородкин, 2015 и др.], так и отдельные крупные регионы [Афанасенков и др., 2018 и др.].

В перечисленных выше работах большинство исследователей полагает, что накопление осадков малышевской свиты происходило преимущественно в обстановках мелководного морского бассейна и его прибрежных частей. Однако для территории, где малышевскому горизонту соответствует верхнетюменская подсвита, однозначности в результатах палеогеографических реконструкций нет.

Диаметрально противоположными в этом вопросе являются позиции, изложенные в работах [Курчиков, Бородкин, 2015] и [Гурари и др., 2005]. Так, А.Р. Курчиков и В.Н. Бородкин считают, что осадки верхнетюменской подсвиты накапливались в континентальных условиях низменной аккумулятивной равнины, тогда как в работе 
Ф.Г. Гурари с соавторами на большей части этой территории показано распространение морского бассейна, на что обращалось внимание выше.

Согласно третьей точке зрения, промежуточной между вышеуказанными, формирование малышевского горизонта в северных районах предполагается в обстановках дельтовой равнины, а в центральных и южных районах в обстановках озерноаллювиальной равнины, временами заливавшейся морем [Мясникова и др., 2012].

Отдельно можно выделить палеогеографические схемы в работах [Мкртчян, Филина, 1985; Kontorovich et al., 2013], составленные для позднебатского времени. Схемы объединяют близкие представления на распространение палеогеографических областей морского, переходного и континентального осадконакопления, их размеры и расположение в пределах Западно-Сибирского осадочного бассейна.

Предполагается, что в дальнейшем для успешной реализации поисковых и разведочных работ результаты детальных исследований позволят осуществлять в разных районах Западной Сибири ориентированный поиск тел-коллекторов различного генезиса, геометрии (формы) и качества, которые, как отмечал Ф.Г. Гурари: «...кодировались условиями их седиментации...» [Гурари, 1989, стр. 57]. На детальных палеогеографических картах должны выделяться русловые, проточные, баровые, дельтовые, пляжевые и другие фации, с которыми связаны структурно-литологические и литологические ловушки углеводородов. Для Западной Сибири примеры такой детализации приведены в работах [Kontorovich et al., 2010; Казаненков и др., 2019; Kazanenkov, 2019].

\section{МЕТОДИКА ИССЛЕДОВАНИЙ И ФАКТИЧЕСКИЙ МАТЕРИАЛ}

Построение палеогеографических карт базировалось на результатах фациальной интерпретации материалов стандартного (ПС, ИК, КС, КВ) и радиоактивного (ГК и НГК) каротажа, а также на изучении описания керна опорных, параметрических, поисковых и разведочных скважин, вскрывших малышевский горизонт на территории Западной Сибири и Енисей-Хатангского регионального прогиба.

Основой при фациальной интерпретации материалов ГИС послужили эталонные седиментационные разрезы горизонта $\mathrm{Ю}_{2}$ в Широтном Приобье, по которым в совокупности выделено 27 обстановок (фаций) осадконакопления в составе шести генетических комплексов отложений: аллювиальный и озерный (континентальная группа), дельтовый и прибрежно-континентальный (переходная группа), прибрежно-морской и мелководно-морской (морская группа) [Kontorovich et al, 2010].

Количество скважин с проинтерпретированными материалами ГИС составило порядка 4000, а с материалами описания керна, отобранного в интервалах верхнетюменской подсвиты и малышевской свиты - 250. Описание керна собрано из трех типов источников: дела скважин, фондовые материалы ИНГГ СО РАН и публикации. Расположение скважин показано на рисунке 1.

Следует отметить, что описания керна из дел скважин различаются по детальности. В ряде скважин оно ограничено только перечислением основных типов пород без характеристики их текстур и других деталей. По этой причине не всегда удавалось выделить какие-либо важные для определения фаций особенности в строении разрезов, из-за чего делался акцент только на литолого-фациальную интерпретацию материалов геофизических исследований скважин. 
Из наиболее полных описаний использовалась информация о литологическом составе и текстурах пород, наличии или отсутствии в них включений сидерита и пирита, следов биотурбации, крупноразмерных фрагментов растений и остатков корней, прослоев и пластов углей.

Дополнительными критериями при фациальной интерпретации материалов ГИС служили минералогические индикаторы форм железа: пирит и сидерит. В общем виде наличие в керне пирита указывает на восстановительные условия, которые характерны для морского бассейна, а сидерита - на слабо-восстановительные условия обстановок прибрежных равнин, надводной части дельтового комплекса и др. Также использовалась информация о находках следов жизнедеятельности (ихнофоссилий), характеристика ассоциаций которых для батских отложений детально описана в работе [Вакуленко и др., 2005]. Выполненный авторами этой публикациии ихнофациальный анализ показал, что биотурбация осадков наиболее характерна для обстановок дельтовой равнины (в первую очередь внутридельтовых, или окраинных заливов), лагунного побережья и предфронтальной зоны пляжа, в меньшей степени - пойменных и озерных.

Отложениям, сформировавшимся в континентальных условиях, главным образом, в обстановках стариц, пойменных и заболачивающихся пойменных равнин, свойственны крупноразмерные остатки флоры, остатки корневых систем, прослои и пласты углей.

По находкам макрофауны, микрофауны и микрофитопланктона определялись слои морских, прибрежно-морских (солоноватоводных) или пресноводных (редко) фаций. Для выявления в разрезах таких слоев на отдельном этапе исследований из многочисленной опубликованной литературы по биостратиграфии юрских разрезов и из фондов ИНГГ СО РАН автором был собран и систематизирован палеонтологический материал, который прошел ревизию на соответствие определений биоты малышевскому горизонту в его современном стратиграфическом объеме (верхний байос - низы верхнего бата). Это необходимо было сделать, поскольку ранее его верхняя граница проводилась в нижнем келловее. Ревизия определений макрофауны выполнялась Б.Н. Шурыгиным, микрофауны Б.Л. Никитенко, микрофитопланктона А.А. Горячевой, в результате чего было установлено, что часть палеонтологических находок из верхних слоев тюменской и малышевской свит относится к васюганскому горизонту.

Места находок были отмечены на каротажных диаграммах, что в дальнейшем позволило создать каталог, характеризующий наличие морской биоты в каждом продуктивном горизонте $\left(Ю_{2}, Ю_{3}\right.$ и $\left.Ю_{4}\right)$ в отдельности и выявить особенности ее распространения в этих горизонтах на территориях развития тюменской и малышевской свит.

Под термином «продуктивный горизонт» понимается проницаемое породное телоколлектор, которое в разрезе одной скважины может быть представлено как единое, преимущественно песчаное или песчано-алевритовое тело, а в разрезе соседней скважины, оно может состоять из нескольких проницаемых пластов, разделенных пачками глин. Из этого следует, что пласты являются составными частями продуктивных горизонтов. Именно в таком понимании термины «продуктивный горизонт» и «продуктивный пласт» используются в последующем тексте.

Региональный масштаб исследований, выполненных в границах всего ЗападноСибирского осадочного бассейна, обусловил картирование только палеогеографических областей, границы между которыми проводились по смене доминирующего типа седиментогенеза. В настоящей работе обоснование границ определялось количеством и 
качеством фактического материала и в дальнейшем, по результатам более крупномасштабных исследований в отдельных зонах, может уточняться.

При составлении региональных палеогеографических схем учитывались карты изопахит малышевского горизонта Западной Сибири [Мясникова и др., 2009], а также Карско-Ямальского региона и Енисей-Хатангского регионального прогиба, которые были построены специалистами ИНГГ СО РАН.

Максимальные толщины малышевского горизонта по материалам глубокого бурения установлены в осевой части Енисей-Хатангского регионального прогиба, где они составляют порядка 480 м. В Ямало-Гыданском районе значения толщин изменяются от 45-50 до 190-195 м. В северных районах Западной Сибири максимальными толщины исследуемый интервал разреза характеризуется в районе Большехетской впадины. В стратотипическом разрезе скв. Самбургская № 700 общая толщина горизонтов $Ю_{2}-Ю_{4}$ равна 226 м. В южном направлении наблюдается постепенное сокращение толщин. Так, в Широтном Приобье значения изменяются в диапазоне 80-100 м. На моноклиналях Внешнего пояса толщины горизонтов $Ю_{2}-Ю_{4}$ не превышают 50 м [Мясникова и др., 2009].

Выделение в изученных скважинах интервалов продуктивных горизонтов $Ю_{2}, Ю_{3}$ и $\mathrm{Ю}_{4}$ осуществлялось с учетом индексации песчаных тел в скважинах, утвержденных в качестве стратотипических для нижней и средней юры [Решение..., 1986]. Расположение этих скважин приведено на рисунке 1.

\section{ПАЛЕОГЕОГРАФИЯ ЗАПАДНО-СИБИРСКОГО ОСАДОЧНОГО БАССЕЙНА НА ВРЕМЯ ФОРМИРОВАНИЯ ГОРИЗОНТОВ $\mathrm{Ю}_{2}-\mathrm{Ю}_{4}$}

По результатам интерпретации обстановок осадконакопления в разрезах скважин было установлено, что в течение малышевского времени ландшафты Западно-Сибирского осадочного бассейна менялись неоднократно и при этом значительно. Наиболее отчетливо это проявилось в позднемалышевское время (время формирования горизонта $\mathrm{Ю}_{2}$ ).

Поэтому в процессе исследований выполнены палеогеографические реконструкции для отдельных отрезков малышевского времени. В эти временные отрезки накапливались осадки горизонтов $Ю_{4}, Ю_{3}$ и верхней части горизонта $Ю_{2}$. При построении палеогеографической схемы на время накопления верхней части горизонта $Ю_{2}$ учтены результаты детальных исследований в центральных и южных районах бассейна [Kontorovich et al., 2010; Казаненков и др., 2019].

\section{ПАЛЕОГЕОГРАФИЯ ВРЕМЕНИ НАКОПЛЕНИЯ ГОРИЗОНТА Ю4}

K началу малышевского времени Западная Сибирь представляла собой равнину со сглаженным рельефом, образовавшуюся в результате регрессии моря в леонтьевское время (верхи нижнего - низы верхнего байоса). Известно, что это море достигало южных районов осадочного бассейна, о чем свидетельствует обнаруженная в керне Барабинской опорной скважины двустворка Tellina sp., или Tancredia sp. (написание в разных работах различно), средой обитания которой была прибрежная зона

Согласно выполненным реконструкциям в раннемалышевское время морской бассейн, назовем его Южно-Карское палеоморе, существовал в северных районах Западной Сибири (рис. 2). На юге его прибрежная зона ограничивалась параллелью примерно $68^{0}$ с.ш. Проведение южной границы моря в столь высоких широтах подтверждается континентальным генезисом отложений горизонта $\mathrm{Ю}_{4}$, установленным по разрезам скважин Уренгойской площади. 
На юго-востоке Южно-Карское палеоморе соединялось с Хатангским проливом, а на северо-западе имело связь с Арктическим бассейном через Южно-Новоземельский пролив, который, как предполагается, существовал на территории современного Южного острова и южной и юго-западной частях Северного острова архипелага Новая Земля. Основанием для этого предположения являются находки аммонитов, белемнитов и двустворок нижнего бата в делювиальных и элювиальных отложениях на северо-западе Южного и юго-западе Северного островов архипелага Новая Земля [Дибнер, 1962].

Согласно представлениям В.Д. Дибнера, источники сноса обломочного материала в батское время в этой части бассейна находились к северо-востоку от Новой Земли, на основании чего им сделан вывод о существовании в это время на территории всего архипелага морского бассейна с наклоном дна с северо-востока на юго-запад.

Ранее связь морского бассейна на севере Западной Сибири с Арктическим бассейном предполагалась через Гыданский пролив, который образовался в байосский век [Сакс, Ронкина, 1958]. На палеогеографической карте байосского и батского веков [Атлас..., 1968] он разделяет Новоземельскую полуостровную гряду и остров Таймыр. Позднее существование этого пролива в батский век предполагалось также в работе [Kontorovich et al., 2013].

Необходимо, однако, иметь ввиду, что сейсморазведочные работы последних лет показали, что между северным окончанием архипелага Новая Земля и полуостровом Таймыр в основании осадочного чехла выделяется линейно вытянутый, контрастный эрозионный выступ архейско-протерозойского фундамента - Северо-Сибирский порог [Kontorovich V. and Kontorovich A., 2019].

По результатам бурения Свердрупской параметрической скважины на югозападном склоне порога он перекрыт толщей (166 м) песчаников и алевролитов верхней юры [Грамберг и др., 1985], что является доказательством отсутствия в перекрывающем этот выступ осадочном разрезе отложений средней юры.

Вероятно, среднеюрские отложения отсутствуют и к востоку от Северо-Сибирского порога (северная часть Карского моря), где по результатам интерпретации материалов морской сейсморазведки между мощной толщей палеозойских и маломощной мезозойских (меловых?) отложений выделена эрозионная поверхность, которая, как считают В.А. Конторович и А.Э. Конторович, сформировалась в результате длительного перерыва в осадконакоплении [Kontorovich V. and Kontorovich A., 2019].

На основании изложенного предполагается, что к востоку от Южно-Карского палеоморя в малышевское время находился крупный палеоостров, с которого поступал обломочный материал в его восточную и северо-восточную части. Палеоостров объединял территории Таймыра, островов архипелага Северная Земля, Северо-Сибирского порога и Северного острова архипелага Новая Земля.

Глубины морского бассейна в пределах большей части акватории не превышали 25 м. В центральной части моря накапливались алевриты, чередующиеся с глинами, реже с песками. В направлении берега содержание песчано-алевритовых осадков закономерно увеличивалось. Более глубоководные условия осадконакопления существовали на востоке Хатангского пролива. В его осевой части, где накапливались преимущественно глинистые илы. В настоящее время разрезы низов малышевской свиты, представленные аргиллитами, вскрыты скважинами на Новой, Кубалахской, Балахнинской и других площадях. О существовании относительно глубоководных условий в восточной части Хатангского пролива свидетельствует также находка на Новой площади (скв. № 1) двустворки Malletia, 
которая обитала, согласно палеонтологическим реконструкциям [Шурыгин, 2005], на глинистых илах при глубине моря более 100 м. Вероятно, аналогичные глубины существовали и к западу от современного полуострова Ямал, в районе Южно-Карской впадины.

Морской бассейн был с нормальной соленостью вод, на что указывают комплексы двустворок из низов малышевской свиты, найденные в керне скважин Харасавейской и Арктической площадей. На территории Хатангского пролива остатки двустворок и фораминифер из низов малышевской свиты обнаружены в керне скважин Дерябинской, Хабейской, Майской, Джангодской, Рассохинской и Новой площадей.

По периферии морского бассейна выделена область переходного осадконакопления, в пределах которой формирование горизонта $Ю_{4}$ происходило в обстановках лагунного побережья, прибрежных и дельтовых равнин. Эта область характеризуется пестрым составом отложений (от средне- и крупнозернистых песчаников до алевритов и глин), часто с резкой сменой гранулометрического состава пород в плане, свойственной накоплению терригенных осадков в разных гидродинамических условиях. В описаниях керна отмечено наличие в отложениях растительного детрита и тонких пропластков углей, вероятнее всего, образовавшихся из растительности маршевых болот прибрежных и дельтовых равнин.

С юга к области переходного осадконакопления примыкала обширная аллювиально-озерно-болотная равнина, которая занимала наиболее низменные участки палеорельефа в приосевой части бассейна. Равнину пересекали реки, которые из-за выровненного рельефа, как предполагается, были меандрирующего типа с извилистыми руслами, обрамленными широкими поймами.

В пределах равнины в болотах, поймах рек и центральных частях зарастающих озер шло накопление глин и глинистых алевритов, часто с обилием растительного детрита и крупными фрагментами (листья, стебли и др.) растительности. Нередко в этих условиях формировались прослои торфяников. В русловых обстановках накапливались пески. Алевритовый материал осаждался во время паводков на поймах в виде наносов (конусов выноса), а также в старичных озерах.

Аллювиально-озерно-болотная равнина также выделена на крайнем юго-востоке бассейна. Основанием для ее выделения послужил разрез Чулымской опорной скважины, в котором интервал стратиграфического аналога верхнетюменской подсвиты представлен преимущественно глинистой толщей с прослоями алевролитов и пластами углей [Пояркова, 1961].

Наибольшую площадь территории осадочного бассейна в раннемалышевское время занимала аккумулятивная озерно-аллювиальная равнина. На северо-востоке она была развита неширокой полосой вдоль области переходного осадконакопления. Внешний контур ее распространения контролировался возвышенными холмистыми равнинами, окружавшими осадочный бассейн.

По результатам фациальной интерпретации материалов ГИС, дополненных результатами седиментологических исследований керна из скважин ТевлинскоРусскинской, Южно-Конитлорской, Усть-Балыкской, Восточно- и Южно-Сургутской площадей, озерно-аллювиальная равнина также выделена в районе относительно приподнятого в палеорельефе раннемалышевского времени участка территории, которому в современном структурном плане кровли тюменской свиты соответствует Сургутский свод. 
В пределах озерно-аллювиальной равнины формировались осадки с близким содержанием глинистого и песчано-алевритового материала. Однако здесь в разрезах скважин нередко отмечаются мощные песчаные тела, которые по литологическому составу и текстурам, указанным в описаниях керна, а также по формам диаграмм ПС и ГК рассматриваются как русловые. Следует отметить, что разрезы горизонта $Ю_{4}$ в зонах распространения озерно-аллювиальной равнины, в целом, отличаются меньшим количеством угольных пластов. Это может свидетельствовать о незначительном уровне заболачивания территории.

Основными внешними источниками сноса служили на востоке осадочного бассейна западная часть Средне-Сибирской палеовозвышенности и Енисейский кряж, а на западе Уральская палеовозвышенность. На юге и юго-востоке обломочный материал поступал в бассейн с Казахстанской и Алтае-Саянской горных систем. По данным А.В. Гольберта с соавторами в среднеюрскую эпоху высота отдельных горных хребтов на возвышенных холмистых равнинах Северного Казахстана и Алтае-Саянской области составляла до 2000 м [Гольберт и др., 1968].

Как было отмечено ранее, на северо-востоке в раннемалышевское время существовал крупный палеоостров Таймыр, который представлял собой источник сноса терригенного материала, поступавшего в Южно-Карское палеоморе и северную часть Хатангского пролива.

Внутренние источники обломочного материала, представлявшие собой выступы фундамента, выделены по отсутствию на локальных участках в разрезе осадочного чехла тюменской свиты. Большинство из них находилось вдоль западного, юго-западного и южного обрамления бассейна. $\mathrm{K}$ наиболее крупным из них относятся Висимский, Шаимский, Тобольский, Старосолдатский, Усть-Тегусский и Межовский.

По завершению формирования горизонта $Ю_{4}$ на большей части территории распространения тюменской свиты шло накопление осадков глинисто-углистой пачки с прослоями морских отложений, о наличии которых свидетельствуют остатки двустворчатых моллюсков, установленные в керне скважин Уренгойская № 266 (инт. 38323847 м), Тайлаковская № 591э (инт. 2791-2797 м) и фораминифер в образцах керна из скважины Крючковская № 30 (инт. 3051-3068 м). Подмечено, что выше и ниже этих прослоев в разрезах залегают пласты углей. Вследствие этого напрашивается вывод о кратковременном проникновении морских вод по пониженным участкам палеорельфа в район современной Юганской мегавпадины. Возможно формирование пачки было связано с повышением базиса эрозии.

\section{ПАЛЕОГЕОГРАФИЯ ВРЕМЕНИ НАКОПЛЕНИЯ ГОРИЗОНТА Ю}

В среднемалышевское время площадь морского бассейна не изменилась. Его большая часть оставалась мелководной, с глубинами не более 25 м. Наиболее глубоководные зоны в среднемалышевское время сохранились в Хатангском проливе и в северной части Южно-Карского моря.

Морской бассейн имел нормальную соленость вод, что подтверждается находками аммонитов среднего бата на островах архипелага Новая Земля (без указания местоположения) [Палеогеография..., 1983] и Cranocephalites (?)sp. на Рассохинской площади в скважине № 1 [Булынникова и др., 1972], а также двустворок, обитавших в условиях верхней сублиторали, характерных для слоев с Meleagrinella ovalis и Dacryomya 
ovum. среднего-верхнего бата, в керне скважин Харасавейской (скв. № 45), Бованенковской (скв. № 130) и Арктической (скв. № 16) площадей [Шурыгин и др., 2000].

Область переходного осадконакопления оставалась в прежних границах. В ее пределах в обстановках лагунного побережья, прибрежных и дельтовых равнин накапливались песчаники, алевролиты и аргиллиты с преобладанием песчаноалевритовых пород. Согласно описаниям керна, для пород этой области характерны включения мелкокристаллического пирита, вертикальные и горизонтальные следы биотурбации, редкие, тонкие пропластки и линзы угля, крупноразмерные углефицированные фрагменты растений (листья, стебли), остатки корневой системы.

В скважине Малохетская № 10 к горизонту Юз приурочены находки раковинного детрита, а также комплекса фораминифер батского яруса (определения Н.В. Шаровской).

Площадь аллювиально-озерно-болотной равнины в сравнении с предыдущим отрезком малышевского времени сохранилась примерно в тех же размерах. В ее пределах в обстановках озер и речных пойм отлагались обогащенные растительным детритом глинистые и глинисто-алевритовые илы с маломощными прослоями песков. В болотах формировались торфяники. Песчано-алевритовый материал аккумулировался, главным образом, в обстановках меандровых кос и русловых отмелей речных систем, образуя сравнительно узкие линейно вытянутые в плане тела.

Континентальный режим осадконакопления, господствовавший на всем протяжении среднемалышевского времени, неоднократно прерывался непродолжительными ингрессиями моря. Об этом свидетельствуют единичные находки макро-, микрофауны и микрофитопланктона на разных уровнях горизонта Юз (рис. 3). При этом обращает на себя внимание проникновение морских вод не только в центральные районы бассейна, как это было на этапе формирования глинисто-углистой пачки, разделяющей горизонты $Ю_{4}$ и $Ю_{3}$, но и на юго-запад, в район склонов Шаимского палеоподнятия. Из-за значительного расстояния между скважинами и отсутствия какихлибо реперов на каротажных диаграммах и в керне эти слои не коррелируются по площади.

Наличие морских прослоев в разрезе, представленном преимущественно континентальными отложениями, предопределило выделение на палеогеографической карте для среднемалышевского времени равнины периодически заливавшейся морем.

Наиболее точно этап формирования продуктивного горизонта $Ю_{3}$ можно охарактеризовать цитатой из работы выдающегося ученого геолога-нефтяника И.М. Губкина - «...шла непрерывная борьба суши и моря с чередованием трансгрессии и регрессии...» [Губкин, 1975, стр. 124].

Большая часть площади аккумулятивной озерно-аллювиальной равнины, располагалась в пределах восточной, юго-восточной и южной частей бассейна. На этой обширной территории широкое развитие получили речные долины, в пределах которых шло накопление песчано-алеврито-глинистых осадков в русловых и пойменных обстановках аллювиального комплекса. Часть территории занимали озера. Подмечено, что в направлении обрамления осадочного бассейна количество песчаного материала в разрезе горизонта $Ю_{3}$ постепенно увеличивается.

\section{ПАЛЕОГЕОГРАФИЯ ВРЕМЕНИ НАКОПЛЕНИЯ ВЕРХНЕЙ ЧАСТИ ГОРИЗОНТА}


Выполненные ранее детальные комплексные исследования (седиментологические исследования керна, интерпретация материалов ГИС, палеонтологические находки, ихнологические наблюдения) показали, что верхняя часть верхнетюменской подсвиты в центральных районах Западной Сибири формировалась в полифациальных условиях. Согласно результатам этих исследований, в разрезе горизонта Ю $_{2}$ выявлено шесть генетических комплексов: аллювиальный, озерный (континентальная группа), дельтовый, прибрежно-континентальный (переходная группа), прибрежно-морской и мелководноморской (морская группа) [Kontorovich et al., 2010].

Нижняя часть горизонта повсеместно представлена континентальными отложениями аллювиально-озерно-болотной и озерно-аллювиальной равнин. По мере трансгрессии морского бассейна на юг осадки этих равнин сменялись дельтовыми и прибрежно-континентальными. Осадки переходной группы фаций перекрывались прибрежно-морскими, которые на заключительном этапе формирования горизонта Ю $_{2}$ сменялись мелководно-морскими.

Приведенное ниже описание характеризует палеогеографию времени накопления осадков самой верхней части горизонта Ю $_{2}$ (предвасюганское время максимальной трансгрессии моря).

Площадь мелководной акватории Южно-Карского палеоморя $\mathrm{k}$ концу малышевского времени существенно увеличилась. В процессе трансгрессии море достигло территорий Красноленинского и Шаимского районов на юго-западе и Демьянского района на юге (рис. 4).

Наступление трангрессирующего моря на заключительной стадии накопления осадков горизонта $\mathrm{Ю}_{2}$ подтверждается многочисленными палеонтологическими находками в центральной, южной и юго-западной частях бассейна. Обращает на себя внимание следующая особенность в распределении обнаруженной фауны. В плане территория, в пределах которой в горизонте $Ю_{2}$ найдена морская биота, с юго-востока ограничена спрямленной линией, прослеживающийся от Мангазейской и Черничной площадей на северо-востоке до Южно-Кальчинской на юго-западе, с отклонением на юговосток в районе Юганской мегавпадины. Можно предположить, что такая особенность в размещении находок фауны указывает на приблизительное положение береговой линии морского бассейна в позднемалышевское время (см. рис. 4). Подтверждением этому является анализ определений двустворок, результаты которого показали количественное преобладание моллюсков родов Arctica и Tancredia, предпочитавших, согласно работе [Захаров, Шурыгин, 1978], селиться на алеврито-песчаных осадках в прибрежной зоне.

Наиболее глубоководные зоны морского бассейна в позднемалышевское время попрежнему располагались в Хатангском проливе и в северной части Южно-Карского палеоморя. Предполагается, что площадь этой зоны в Хатангском проливе расширилась в западном направлении и приблизилась к юго-западной части Таймырского палеоострова.

Море неширокой полосой окаймляла область переходного осадконакопления, в пределах которой обломочный материал осаждался в обстановках лагунного побережья, а также прибрежных и дельтовых равнин. Вероятно, в связи с понижением общего базиса эрозии в позднемалышевское время на территории современного Сургутского свода располагалась островная суша с абразионно-аккумулятивными берегами лагунного побережья. На наиболее приподнятых в палеорельефе участках внутренней части Сургутского палеоострова осадки накапливались в обстановках озер и болот. 
C запада и востока, занимая пониженные участки палеорельфа, к области переходного осадконакопления примыкала аллювиально-озерно-болотная равнина. В ее пределах продолжали формироваться осадки болот, рек, пойм и озер с признаками зарастания и заболачивания.

Аккумулятивные озерно-аллювиальные равнины занимали значительные площади на юге и юго-востоке бассейна, где до конца малышевского времени сохранялся относительно возвышенный рельеф. От внутренних районов к обрамлению роль аллювиальных фаций в разрезе увеличивается. Это отчетливо наблюдается при корреляции разрезов скважин.

K предвасюганскому времени произошла пенепленизация рельефа основных источников сноса терригенного материала. Однако, согласно представлениям Ф.Г. Гурари с соавторами в позднебатское время в областях денудации южного обрамления осадочного бассейна отметки рельефа достигали 1000-1500 м [Гурари и др., 1988]. Надо полагать, что в начале малышевского времени они были выше.

Предполагается, что в средне-позднемалышевское время активизировались тектонические процессы, которые привели к воздыманию Таймырской палеовозвышенности. На Гыданской и Дерябинской площадях, наиболее близко расположенных к этой области размыва, в разрезе малышевской свиты это проявилось в регрессивной направленности изменения гранулометрического состава пород от глинистоалевритовых в нижней части к преимущественно песчаным в верхней части. Следует отметить, что ранее о поднятии Таймырской палеовозвышенности во второй половине бата сообщалось в работе 3.3. Ронкиной [1965].

\section{ЗАКЛЮЧЕНИЕ}

Из вышеприведенных материалов, характеризующих палеогеографию на время формирования горизонтов $Ю_{4}, Ю_{3}$ и $Ю_{2}$, следует, что на территории Западно-Сибирского осадочного бассейна режим осадконакопления на протяжении всего малышевского времени был крайне неустойчивым. Особенно отчетливо это проявилось на территории распространения тюменской свиты.

К началу малышевского времени Западная Сибирь представляла собой равнину со сглаженным рельефом, образовавшуюся в результате регрессии моря леонтьевского времени.

Вследствие понижения общего базиса эрозии и, вероятно, в какой-то степени оживления тектонических процессов в областях сноса, в начале малышевского времени значительно увеличилось количество поступавшего в седиментационный бассейн песчаного материала. Песок транспортировался речными потоками на большие расстояния, формируя линейно вытянутые тела горизонта $Ю_{4}$, представляющий собой в настоящее время породы-коллекторы.

На большей части территории седиментационного бассейна была развита аллювиально-озерно-болотная равнина, занимавшая пониженные участки палеорельефа в приосевой зоне. На западе, востоке, юге и юго-востоке она сменялась озерноаллювиальными равнинами.

Мелководный морской бассейн раннемалышевского времени существовавал только на крайнем севере территории Западной Сибири. Его связь с Арктическим бассейном осуществлялась на юго-востоке через Хатангский пролив, а на северо-западе через ЮжноНовоземельский пролив. 
Mope неширокой полосой окаймляли ландшафты лагунного побережья, прибрежных и дельтовых равнин.

Во время формирования преимущественно глинистой по составу пачки, залегающей между горизонтами $Ю_{4}$ и $Ю_{3}$, произошла первая ингрессия моря, которая, согласно известным в настоящее время находкам макро- и микрофауны, достигла южных районов бассейна.

Во время накопления горизонта $Ю_{3}$ на большей части территории осадочного бассейна существовал преимущественно континентальный режим.

Значительная часть территории северных, центральных и южных районов осадочного бассейна в это время была занята аккумулятивной озерно-аллювиальной равниной, которая обрамляла аллювиально-озерно-болотную равнину. Подмечено, что в направлении внешней границы бассейна количество песчаного материала в разрезах постепенно увеличивается, а содержание углистого материала уменьшается.

Однако палеоландшафты в этот этап формирования отложений в северных, центральных и южных районах седиментационного бассейна были неустойчивыми. Так, в пределы аллювиально-озерно-болотной равнины неоднократно с севера проникало море, которое кратковременно заливало пониженные участки палеорельефа на юге и юго-западе бассейна. Свидетельством этому являются находки различных групп морской биоты, незакономерно распределенные по всему разрезу горизонта Ю

Горизонт $Ю_{2}$ формировался в условиях постепенной трансгрессии моря, которая по смене обстановок осадконакопления в позднемалышевское время, реконструированных по керну скважин, отчетливо фиксируется в разрезах верхней части верхнетюменской подсвиты в центральных и южных районах Западно-Сибирского осадочного бассейна.

Нижняя часть горизонта повсеместно представлена континентальными отложениями аллювиально-озерно-болотной и озерно-аллювиальной равнин. По мере трансгрессии морского бассейна на юг эти отложения сменялись дельтовыми и прибрежно-континентальными, которые в дальнейшем перекрывались прибрежноморскими. На заключительном этапе формирования горизонта Ю $_{2}$ накопление осадков шло в мелководно-морских условиях.

В конце малышевского времени море достигло территорий Красноленинского и Шаимского палеоподнятий на юго-западе и Демьянского палеоподнятия на юге, о чем свидетельствуют многочисленные находки морской биоты. При этом на востоке, юговостоке, юге и западе бассейна до конца малышевского времени сохранились континентальные обстановки осадконакопления.

Таким образом, впервые составленные палеогеографические схемы для отрезков времен формирования горизонтов $Ю_{4}, Ю_{3}$ и верхней части горизонта $Ю_{2}$, в целом, отражают развитие Западно-Сибирского осадочного бассейна в малышевское время.

Необходимо отметить, что набор представленных схем не является исчерпывающим. Так, палеогеографическими реконструкциями остались не охвачены отрезки времени накопления пачек, перекрывающих горизонты $Ю_{4}$ и Ю $_{3}$, а также нижней и средней частей горизонта $Ю_{2}$.

Практическим результатом, полученным на данном этапе исследований, являются рекомендации к ориентированному поиску тел-коллекторов различной геометрии (формы) и качества, песчано-алевритовые отложения которых формировались в континентальных условиях осадконакопления. 
Так, в отложениях аллювиального комплекса (время формирования горизонта $Ю_{4}$ ) песчаные тела имеют вытянутую, в разной степени извилистую форму. Тела коллекторов, образовавшихся в дельтовом комплексе, распространены в виде линз, имеющих в плане достаточно сложную форму. Такие тела в сочетании с телами руслового генезиса характерны для горизонта Юз. Песчаные отложения прибрежно-континентального и прибрежно-морского комплексов образуют тела, распространение которых в плане контролировалось палеорельефом, а также количеством обломочного материала и направлениями его поступления с суши. Коллектора, представленные этими отложениями, являются основными резервуарами нефти и газа в горизонте $Ю_{2}$.

Общие представления о генезисе тел-коллекторов в составе продуктивных горизонтов $Ю_{4}, Ю_{3}$ и $Ю_{2}$ могут учитываться при интерпретации сейсмических данных, включая атрибутный анализ.

В развитие предстоящей работы для планирования поисковых работ представляется важным выполнить палеогеографические реконструкции на временные отрезки малышевского времени в более крупном масштабе (1:200 000, 1:500 000) в пределах отдельных районов Западно-Сибирского осадочного бассейна, для чего необходимо провести детальные седиментологические исследования с построением серии опорных разрезов, отражающих ключевые особенности формирования коллекторов в интервалах отдельных продуктивных горизонтов батского резервуара. Примером таких исследований являются палеогеографические реконструкции, выполненные специалистами ИНГГ СО РАН для территорий Широтного Приобья и южных районов XMAO [Kontorovich et al., 2010]. Эффективность использованного подхода в определении фациального типа отложений и прогноза распространения пород-коллекторов в верхнетюменской подсвите подтверждается фактами открытия новых залежей на Айском (2009 г), Атайском (2010 г), Западно-Икилорском (2016 г), Малоключевом (2014 г), Северо-Покачевском (2007 г), Северо-Покамасовском (2018 г) и других месторождениях Широтного Приобья в пределах зон с высокой вероятностью развития улучшенных коллекторов в горизонте Ю. $_{2}$.

Автор глубоко благодарен академику РАН А.Э. Конторовичу за постановку задачи и ценные советы при подготовке статьи. Автор выражает также благодарность чл.-корр. РАН Б.Н. Шурыгину, д.г.-м.н. Б.Л. Никитенко и к.г.-м.Н. А.А. Горячевой за оказанную помощь в ревизии палеонтологических материалов.

Работа выполнена в рамках проекта ФНИ 0331-2019-0019 «Геология, условия формирования и закономерности размещения залежей углеводородов с трудноизвлекаемыми запасами в Западно-Сибирском мегабассейне».

\section{ЛИТЕРАТУРА}

Атлас литолого-палеогеографических карт СССР. Т. III, Триасовый, юрский и меловой периоды. (гл. ред. А.П. Виноградов) - М., 1968.

Атлас литолого-палеогеографических карт юрского и мелового периодов ЗападноСибирской равнины, масштаб: 1:5000000. редактор И.И. Нестеров - Тюмень, 1976, 85 с.

Атлас палеотектонических и палеогеологических карт Западно-Сибирской нефтегазоносной провинции, масштаб: 1:5000000, составлена: СНИИГГиМС, - 1995. редактор: В.С. Сурков. Электронный ресурс http://www.geokniga.org/maps/6334

Афанасенков А.П., Бордюг А.В., Никишин А.М., Танинская Н.В., Шиманский В.В., Бордунов С.И. Уточнение палеогеографии севера Сибирской платформы с учетом новых данных // Геология нефти и газа, 2018, № 2, - С. 5-23. 
Булынникова А.А., Брадучан Ю.В., Киприянова Ф.В., Ясович Г.С., Аргентовский Л.Ю., Богомякова Е.Д., Бочкарева Н.С., Левина В.И., Ровнина Л.В., Рылькова Г.Е., Тылкина К.Ф., Трандафилова Е.Ф., Широкова Ю.Ф., Шейка Л.Н. Стратиграфопалеонтологическая основа детальной корреляции нефтегазоносных отложений ЗападноСибирской низменности / под ред. И.В. Лебедева. Омск, 1972, Труды ЗапСибНИГНИ, вып. 48, 227 с.

Вакуленко Л.Г., Мадиев М.З., Николенко О.Д., Попов А.Ю., Ян П.А. Следы жизнедеятельности организмов в батских отложениях Широтного Приобья: опыт применения ихнофациального анализа при проведении литолого-фациальных реконструкций // Горные Ведомости. Тюмень, 2005, № 6(13). С. 24-29.

Гольберт А.В., Маркова Л.Г., Полякова И.Д., Сакс В.Н., Тесленко Ю.В. Палеоландшафты Западной Сибири в юре, мелу и палеогене / ред. В.Н.Сакса. М., Наука, 1968, 152 с.

Грамберг И.С., Школа И.В., Бро Е.Г., Шеходанов В.А., Армишев А.М. Параметрические скважины на островах Баренцева и Карского морей // Советская геология, 1985, № 1, - С. 95-98.

Губкин И.М. К вопросу о геологическом строении средней части НефтяноШирванского месторождения нефти / Труды Геологического комитета. Новая серия. СПб.: - 1913. - Вып. 88. - 95 с.

Губкин И.М. Майкопский нефтеносный район. Нефтяно-Ширванская нефтеносная площадь / Труды Геологического комитета. Новая серия. СПб.: - 1912. Вып. 78. - 169 с.

Губкин И.М. Учение о нефти / Издание 3. Редакторы: Варенцов М.И., Трофимук А.А. Наука, Москва, 1975 г, 385 с.

Гурари Ф.Г. Особенности седиментации нижнесреднеюрских отложений на юге Западной Сибири / Геологическое строение и нефтегазоносность юго-востока Западной Сибири: Сб. науч. трудов - Новосибирск, СНИИГГиМС, 1989. - С. 49-58.

Гурари Ф.Г., Будников И.В., Девятов В.П., Еханин А.Е., Казаков А.М., Москвин В.И. Стратиграфия и палеогеография ранней и средней юры Западно-Сибирской плиты / Региональная стратиграфия нефтегазоносных районов Сибири: Сб. науч. трудов Новосибирск, СНИИГГиМС, 1988. - С. 60-75.

Гурари Ф.Г., Девятов В.П., Демин В.И., Еханин А.Е., Казаков А.М., Касаткина Г.В., Курушин Н.И., Могучева Н.К, Сапьяник В.В., Серебренникова О.В., Смирнов Л.В., Смирнова Л.Г., Сурков В.С., Сысолова Г.Г., Шиганова О.В. Геологическое строение и нефтегазоносность нижней - средней юры Западно-Сибирской провинции - Новосибирск: Наука, 2005. - 156 с.

Гурари Ф.Г., Казаринов В.Л., Миронов Ю.К., Наливкин В.Д., Нестеров И.И., Осыко Т.И., Ровнин Л.И., Ростовцев Н.Н., Рудкевич М.Я., Симоненко Т.Н., Соколов В.Н., Трофимук А.А., Чочиа Н.Г., Эрвье Ю.Г. Геология и нефтегазоносность Западно-Сибирской низменности - новой нефтяной базы СССР / под ред. Н.Н. Ростовцева, и А.А. Трофимука. Новосибирск. Изд-во СО АН СССР. 1963. - 202 с.

Гурова Т.И., Казаринов В.П. Литология и палеогеография Западно-Сибирской низменности в связи с нефтегазоносностью. М., Гостоптехиздат, 1962. - 297 с.

Девятов В.П., Казаков А.М. Морская нижняя и средняя юра Западной Сибири / Геология и нефтегазоносность триас-среднеюрских отложений Западной Сибири: Сб. науч. трудов - Новосибирск, СНИИГГиМС, 1991. - С. 40-54.

Дибнер В.Д. Мезозойские отложения Новой Земли / Сборник статей по геологии и нефтегазоносности Арктики. Гостоптехиздат, 1962. Труды НИИГА СССР, Том. 130. - С.5875.

Захаров В.А., Шурыгин Б.Н. Биогеография, фации и стратиграфия средней юры Советской Арктики (по двустворчатым моллюскам) / Новосибирск. Изд-во «Наука», Сибирское отделение. 1978. - 206 с. 
Казаненков В.А., Ян П.А., Вакуленко Л.Г., Попов А.Ю. Палеогеографический контроль нефтеносности малышевского горизонта группы Тайлаковских месторождений (Западная Сибирь) // Геология нефти и газа. - 2019. - № 3. - С. 115-126.

Казаринов В.П. Мезозойские и кайнозойские отложения Западной Сибири. М., Гостоптехиздат, 1958, -324 с.

Карогодин Ю.Н. О связи нефтегазоносности с палеореками (на примере Красноленинского района Западной Сибири) // Доклады Академии наук СССР. - 1966. Том 170. - № 4. - С. 908-911.

Конторович А.Э., Андрусевич В.Е., Афанасьев С.А., Вакуленко Л.Г., Данилова В.П., Злобина О.Н., Ильина В.И., Левчук М.А., Казанский Ю.П., Казарбин В.В., Карогодин Ю.Н., Москвин В.И., Меленевский В.Н., Солотчина Э.П., Фомин А.Н., Шурыгин Б.Н. Геология и условия формирования гигантской Талинской зоны газонефтенакопления в континентальных отложениях нижней юры (Западная Сибирь) // Геология и геофизика. 1995. - № 6. - С. 5-28.

Конторович А.Э., Бабина Н.М., Богородская Л.И., Винокур Б.Г., Зимин Ю.Г., Колганова М.М., Липницкая Л.Ф., Луговцов А.Д., Мельникова В.М., Парпарова Г.М., Рогозина Е.А., Стасова О.Ф., Трушков П.А., Фомичев А.С. Нефтепроизводящие толщи и условия образования нефти в мезозойских отложениях Западно-Сибирской низменности. / Тр. СНИИГГиМСа. Сер. Нефтяная геология, вып. 50. Л., «Недра», 1967. -.223 с.

Курчиков, А.Р., Бородкин В.Н. Характеристика геологического строения и нефтегазоносности юрского нефтегазоносного комплекса Западной Сибири / Зап.-Сиб. филиал Ин-та нефтегазовой геологии и геофизики им. А.А. Трофимука СО РАН. Новосибирск: Издательство СО РАН, 2015. - 140 с.

Мкртчян O.М., Филина С.И. Особенности строения пласта $Ю_{2}$ Западной Сибири и размещения в нём залежей нефти и газа // Геология нефти и газа, 1985, №3, с. 48-53.

Мясникова Г.П., Мухер А.Г., Волков В.А., Сидоров А.А., Тугарева А.В., Кулагина С.Ф., Гончарова В.Н., Солопахина Л.А., Девятов В.П., Сапьяник В.В. Региональные закономерности геологического строения горизонтов нижней-средней юры ЗападноСибирского осадочного бассейна / Материалы XII научно-практической конференции «Пути реализации нефтегазового и рудного потенциала ХМАО - Югры». - ХантыМансийск, 2009. Т 1. - С. 65-86.

Мясникова Г.П., Мухер А.Г., Девятов В.П. Условия седиментации стратиграфических горизонтов юры. Палеогеографические карты / Материалы XV научнопрактической конференции «Пути реализации нефтегазового и рудного потенциала ХМАО - Югры». - Ханты-Мансийск. ИздатНаукаСервис, - 2012. Т.1. - С.77-94.

Палеогеография Севера СССР в юрском периоде / Захаров В.А., Месежников М.С., Ронкина 3.3 и др. - Новосибирск: Наука, 1983. - 191 с.

Пояркова 3.Н. Опорные скважины СССР. Чулымская опорная скважина (Томская область) /Гостоптехиздат, 1961. Труды ВНИГРИ, вып. 183. - 138 с.

Решение совещания по вопросам корреляции и индексации продуктивных пластов мезозойских отложений Тюменской области (20-21 февраля 1986 г.) - Тюмень: ЗапСибНИГНИ, 1986. - 38 с.

Ронкина 3.3. Вещественный состав и условия формирования юрских и меловых отложений севера центральной Сибири / Л., «Недра», 1965, Труды НИИГА, Т. 146. -163 с.

Ростовцев Н.Н. Геологическое строение и перспективы нефтегазоносности южной части Западно-Сибирской низменности / Материалы по геологии, гидрогеологии и нефтегазоносности Западной Сибири. М., Госгеолтехиздат, 1954, Общая серия, вып. 1. - С. 5-60.

Сакс В.Н., Ронкина 3.3. Палеогеография Хатангской впадины и прилегающих территорий на протяжении юрского и мелового периодов // Сборник статей по геологии Арктики. Л.: НИИГА, 1958, - С. 70-89. 
Саркисян С.Г., Корж М.В., Комардинкина Г.Н., Филина С.И., Зонн М.С., Ефремова А.Г. Западная Сибирь в юрском периоде / М.: Наука, 1967. 176 с.

Шурыгин Б.Н. Биогеография, фации и стратиграфия нижней и средней юры Сибири по двустворчатым моллюскам / Новосибирск: Академическое изд-во «Гео», 2005. -154 с.

Шурыгин Б.Н., Никитенко Б.Л., Девятов В.П., Ильина В.И., Меледина С.В., Гайдебурова Е.А., Дзюба О.С., Казаков А.М., Могучева Н.К. Стратиграфия нефтегазоносных бассейнов Сибири. В 9-ти кн. Юрская система. Новосибирск, Изд-во СО РАН. Фил. «Гео», 2000, 480 с.

Kazanenkov V.A. Alluvial paleosystems of the Malyshevsky horizon of the southern areas of the West-Siberian Sedimentary Basin - A determining factor for the distribution of oil reservoirs of the shoestring type // Geology and Mineral Resources of Siberia, 2019, (4). C. 59-66.

Kontorovich A.E., Kontorovich V.A., Ryzhkova S.V., Shurygin B.N.,Vakulenko L.G., Gaideburova E.A., Danilova V.P., Kazanenkov V.A., Kim N.S., Kostyreva E.A., Moskvin V.I., Yan P.A. Jurassic paleogeography of the West Siberian sedimentary basin // Russian Geology and Geophysics. - 2013. - T. 54. - № 8. - C. 972-1012

Kontorovich A.E., Vakulenko L.G., Kazanenkov V.A., Yan P.A., Popov A.Yu., Saenko L.S., Skvortsov M.B., Bykov V.V. Sedimentogenesis and resource potential of Middle-Upper Bathonian reservoirs in the Middle Ob' region // Russian Geology and Geophysics. - 2010. - T. 51. - № 2. - C. 147-158.

Kontorovich V.A., Kontorovich A.E. Geological Structure and Petroleum Potential of the Kara Sea Shelf // Doklady Earth Sciences. - 2019. - T. 489. - № 1. - C. 1289-1293. 
Подрисуночные подписи к статье В.А. Казаненкова Палеогеография Западно-Сибирского осадочного бассейна в позднем байосе - бате

Рис. 1. Схема расположения скважин с изученным описанием керна из малышевского горизонта

1 - граница распространения малышевского горизонта, 2 - скважины с детальными литолого-седиментологическими исследованиями керна, выполненными в ИНГГ СО РАН, 3 - скважины с описанием керна из дел скважин и опубликованных работ, 4 - скважины со стратотипическими разрезами пластов группы $Ю_{2}-Ю_{4}$

Рис. 2. Палеогеографическая схема Западной Сибири на время накопления горизонта $\mathrm{Ю}_{4}$

Палеогеографические области: Области морского осадконакопления: Море мелкое: 1 - глубина моря 50-100 м, 2 - глубина моря менее 50 м; Области переходного осадконакопления: 3 - дельтовые и прибрежные равнины, лагунное побережье; Области континентального осадконакопления: 4 - равнина аккумулятивная аллювиально-озерноболотная; 5 - равнина аккумулятивная озерно-аллювиальная; Области размыва: 6 - равнина возвышенная (денудационная суша), 7 - горы низкие; Прочие условные обозначения: 8 главные направления сноса обломочного материала, Границы: 9 - распространения малышевского горизонта, 10 - Государственная граница, 11- административные границы; Органические остатки: 12 - аммониты, 13 - белемниты, 14 - двустворки, 15 фораминиферы, 16 - крупные остатки растений

Рис. 3. Палеогеографическая схема Западной Сибири на время накопления горизонта $Ю_{3}$

Палеогеографические области: Области морского осадконакопления: Море мелкое: 1 - глубина моря 50-100 м, 2 - глубина моря менее 50 м; Области переходного осадконакопления: 3 - дельтовые и прибрежные равнины, лагунное побережье; 4 равнина, кратковременно заливавшаяся морем; Области континентального осадконакопления: 5 - равнина аккумулятивная аллювиально-озерно-болотная; 6 - равнина аккумулятивная озерно-аллювиальная; Области размыва: 7 - равнина возвышенная (денудационная суша), 8 - горы низкие; Прочие условные обозначения: 9 - главные направления сноса обломочного материала, Границы: 10 - распространения малышевского горизонта, 11 - Государственная граница, 12- административные границы; Органические остатки: 13 - аммониты, 14 - двустворки, 15 - фораминиферы, 16 - микрофитопланктон, 17 - крупные остатки растений

Рис. 4. Палеогеографическая схема Западной Сибири на время накопления верхов верхней части горизонта $Ю_{2}$

Палеогеографические области: Области морского осадконакопления: Море мелкое: 1 - глубина моря 50-100 м, 2 - глубина моря менее 50 м; Области переходного осадконакопления: 3 - дельтовые и прибрежные равнины, лагунное побережье; Области континентального осадконакопления: 4 - равнина аккумулятивная аллювиально-озерноболотная; 5 - равнина аккумулятивная озерно-аллювиальная; Области размыва: 6 - равнина возвышенная (денудационная суша), 7 - горы низкие; Прочие условные обозначения: 8 главные направления сноса обломочного материала, Границы: 9 - распространения малышевского горизонта, 10 - Государственная граница, 11- административные границы; Органические остатки: 12 - аммониты, 13 - двустворки, 14 - фораминиферы, 15 - морские звезды, 16 - микрофитопланктон, 17 - крупные остатки растений 


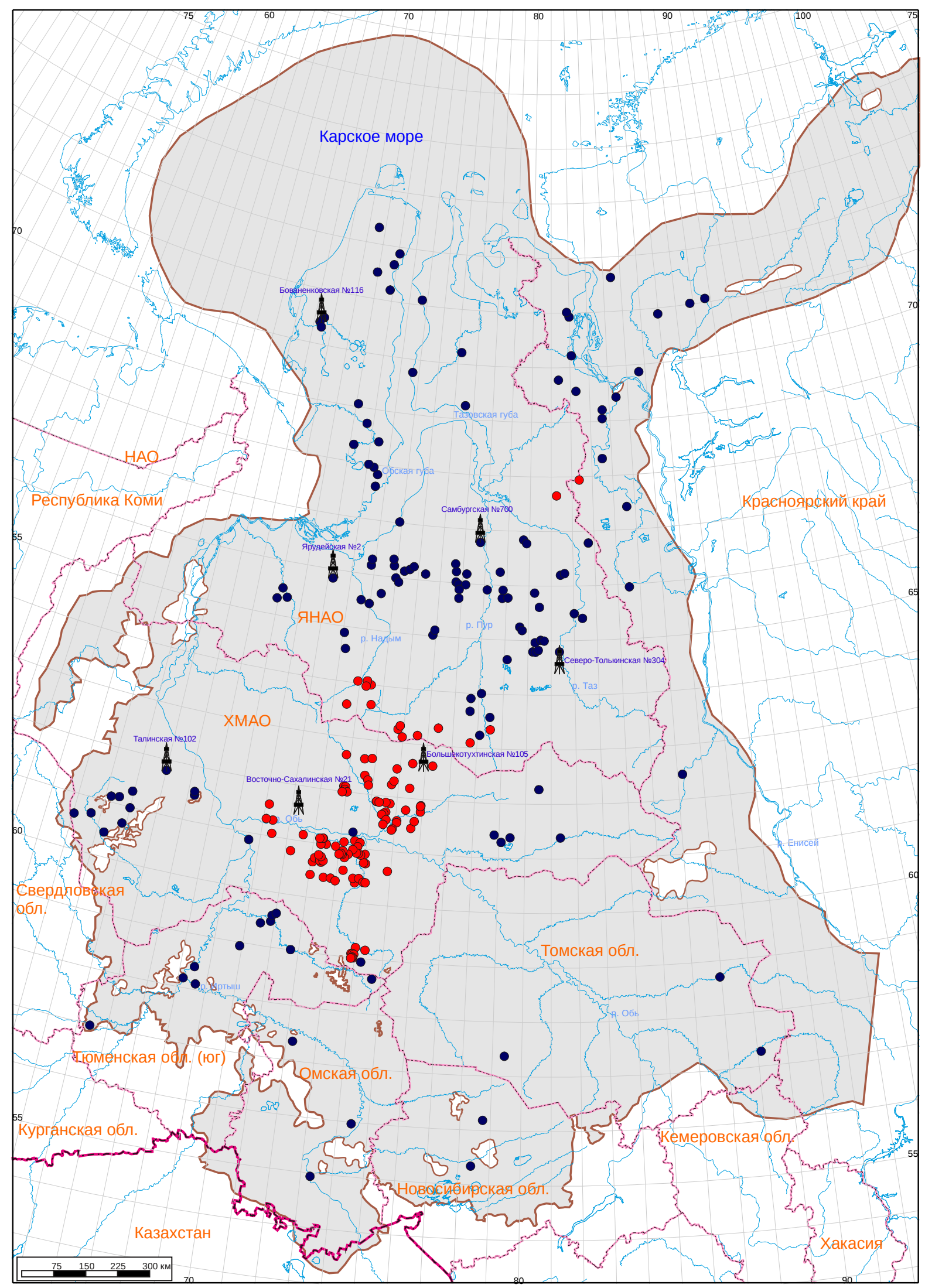




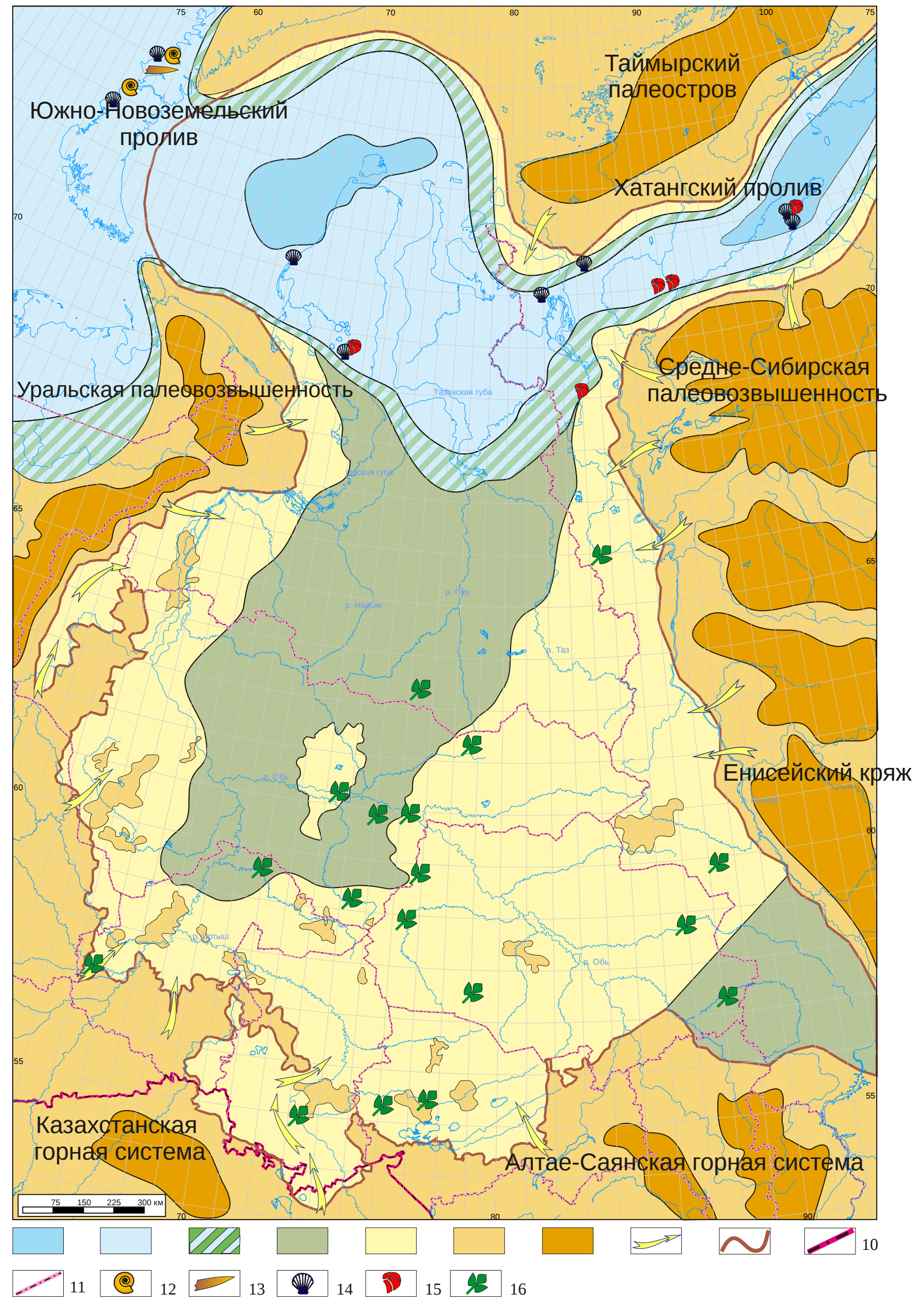

Рис. 2. Палеогеографическая схема Западной Сибири на время накопления горизонта Ю4 


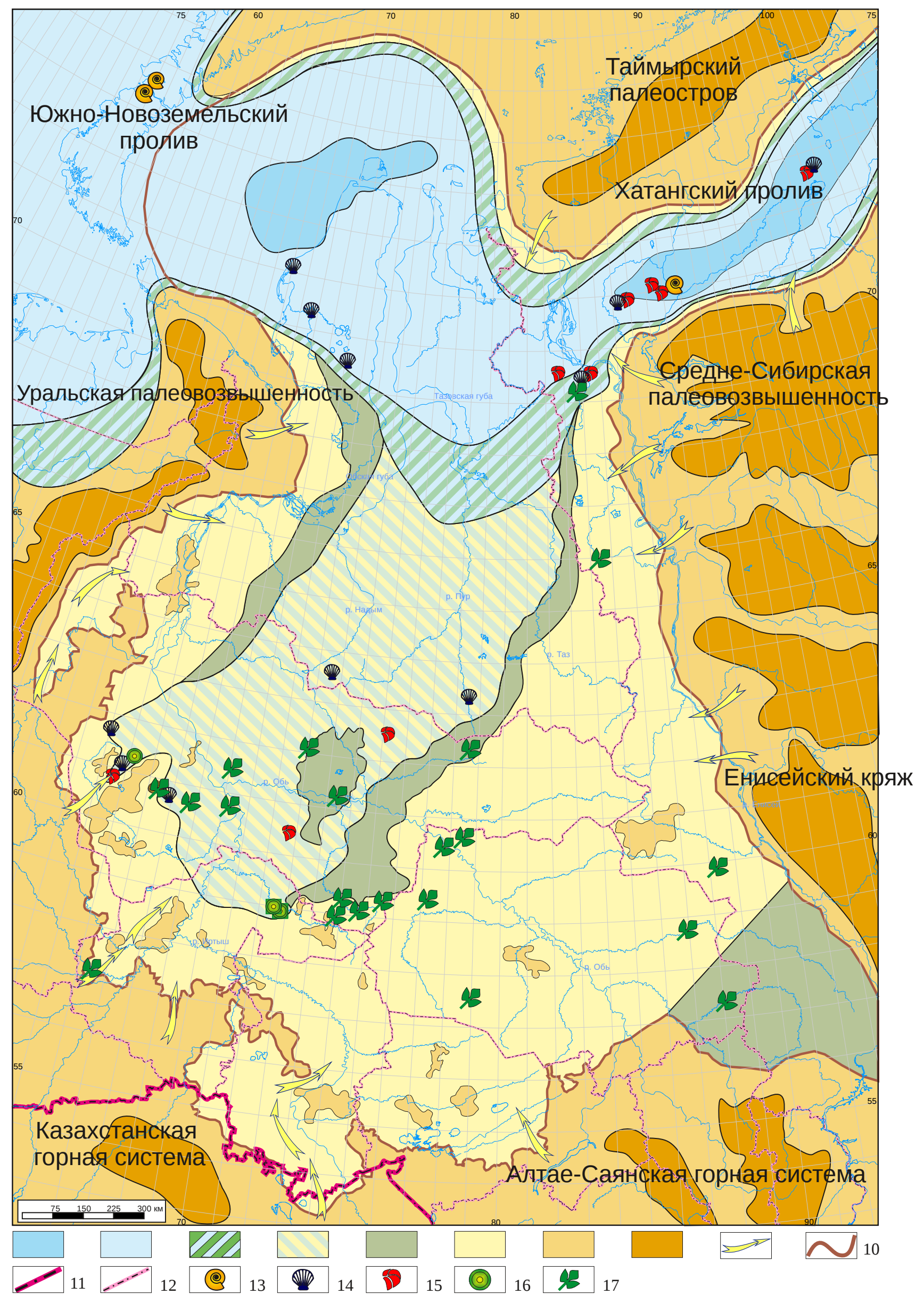

Рис. 3. Палеогеографическая схема Западной Сибири на время накопления горизонта Ю3 


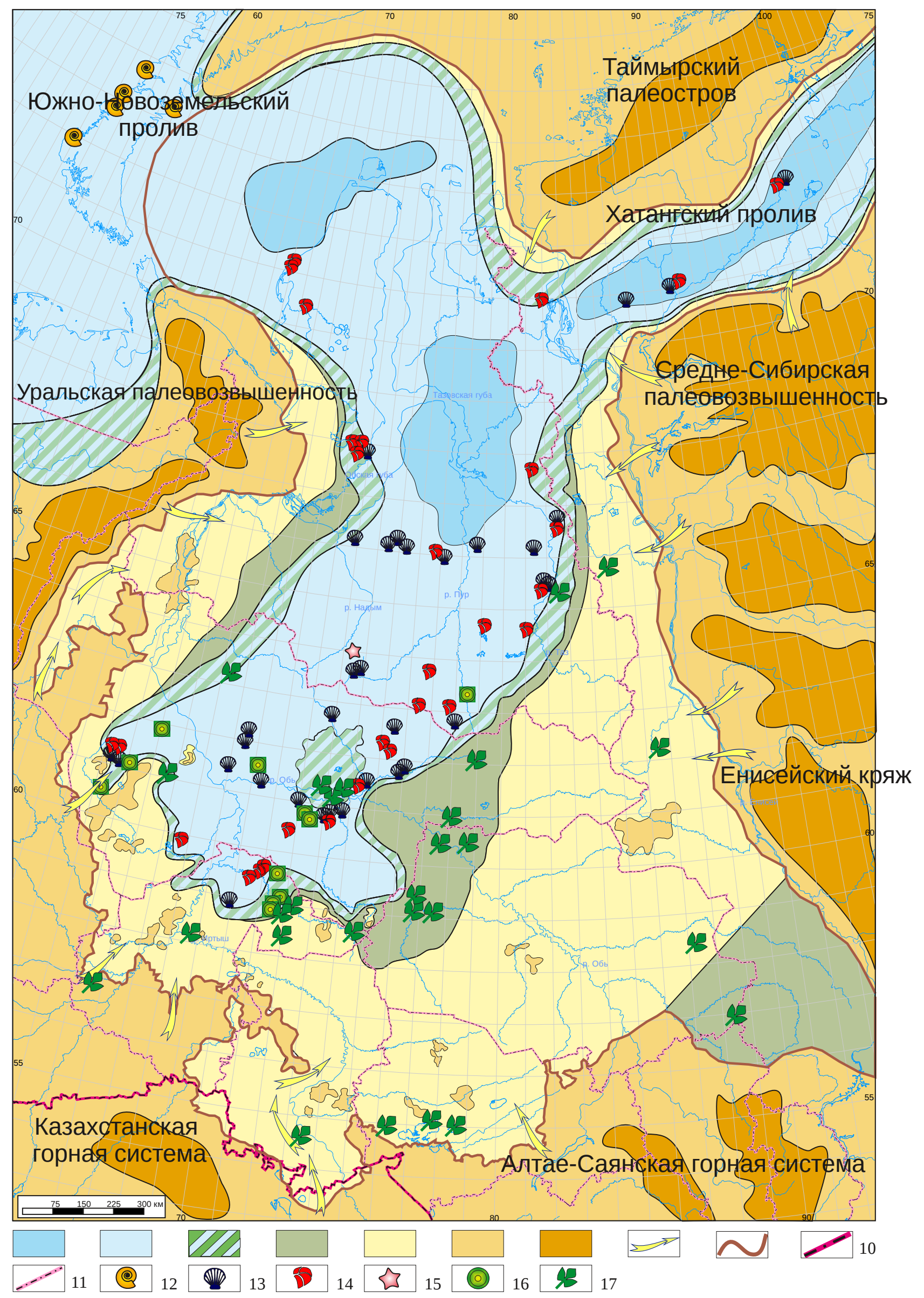

Рис. 4. Палеогеографическая схема Западной Сибири на время накопления верхов верхней части горизонта Ю2 